\section{Neighborhood sociodemographic and environmental contexts and self-rated health among Brazilian adults: a multilevel study}

\author{
O contexto sociodemográfico e ambiental da \\ vizinhança e autopercepção de saúde em adultos \\ de um município do Sul do Brasil: um estudo \\ multinível
}

\author{
1 Programa de Pós-graduação \\ em Saúde Coletiva, \\ Universidade do Vale do Rio \\ dos Sinos, São Leopoldo, \\ Brasil. \\ 2 Prefeitura Municipal de \\ São Leopoldo, São Leopoldo, \\ Brasil. \\ 3 Faculdade de Medicina, \\ Universidade Federal de \\ Pelotas, Pelotas, Brasil. \\ Correspondence \\ M. P. Pattussi \\ Programa de Pós-graduação \\ em Saúde Coletiva, \\ Universidade do Vale do Rio \\ dos Sinos. \\ Av. Unisinos 950, C. P. 275 \\ São Leopoldo, $R S$ \\ 93022-000, Brasil. \\ mppattussi@unisinos.br
}

\section{Abstract}

The aim of this study was to investigate the association between sociodemographic and environmental contexts on self-rated health. A population-based cross-sectional study with a random sample of 38 neighborhoods (census tracts) and 1,100 adults was carried out. Data analysis used multilevel logistic regression. Data from the Brazilian Census of 2000, mean income, years of study of the head of household and mean number of residents per tract were $R \$ 955(S D=586)$, 8 years $(S D=3)$, and 746 residents $(S D=358)$ respectively. Higher prevalences of fair/poor selfrated health were found in neighborhoods with greater populations and lower income/schooling levels. After control for individual variables, the odds for fair/poor self-rated health was twice as high in more populous (OR = 2.04; 95\%CI: 1.153.61) and lower-income neighborhoods (OR = 2.29; 95\%CI: 1.16-4.50) compared to less populous, higher-income ones. Self-rated health depends on individual characteristics and the sociodemographic context of neighborhoods.

Social Conditions; Self Concept; Adult
Cleber Cremonese 1

Vanessa Backes 1,2

Maria Teresa Anselmo Olinto 1

Juvenal Soares Dias-da-Costa 1,3

Marcos Pascoal Pattussi 1

\section{Introduction}

The social sciences, in conjunction with epidemiology, have attempted to understand the relationships between individuals and the contexts in which they live. Context-related effects are understood as the effects of variables defined at a higher level (usually at the group level) on outcomes defined at a lower level (usually the individual level) 1 . The literature demonstrates that individual health tends to vary with context, and that actions at the individual level are often strongly conditioned by social processes operating at the group level 2 .

A neighborhood can be defined as a special construct that represents a geographic unit whose residents share common characteristics. It is a subunit of a larger area, usually - but not exclusively - residential. In the urban context, neighborhoods can indeed often be regarded as the primordial unit of solidarity - both actual and potential - and of social cohesion 3,4.

The characteristics of a given area do not result simply from geographic location, but also from physical and social characteristics - such as behavior, socioeconomic status, local structures, and public service availability - all of which have important implications on the health of those living in the area 5 .

The sociodemographic and environmental context to which an individual is exposed is an important determinant of the health and behav- 
ior of individuals and groups. For example, any person - rich or poor - living in a non-polluted area with fair climate, adequate infrastructure, and easy access to health care will have higher life expectancy 3,6 .

The mental and physical status of an individual is influenced by social surroundings and by the environment. Self-perception of this status is important as a practical and simple method for collecting information on individual health that is ideal for collective interventions and useful for planning, implementing, and monitoring health initiatives and programs 7,8 . Moreover, one simple question - asking a subject to classify his or her own health status - is a strong predictor of morbidity and mortality, a relationship that is maintained after controlling for a variety of physical, sociodemographic, and behavioral variables 7,9.

The association between self-rated health status and characteristics of the place of residence is still understudied in Brazil 4. A search of the PubMed database in June 2009 using the terms "multilevel and health and Brazil" retrieved 21 articles that employ this type of analysis. In these studies, the influence of context has been evaluated on different outcomes, including pulmonary function 10 , type A hepatitis 11 , AIDS 12 , oral health $13,14,15,16,17,18,19,20$, diarrhea 21 , growth deficit 22 , obesity 23 , exclusive breastfeeding 24 , leishmaniasis 25 , mortality 26 , infant mortality 27 , and perinatal mortality 28. Most of these studies were carried out with child and adolescent subjects, and with different Brazilian municipalities as the analysis unit. We could not locate studies evaluating the role of the context - e.g. neighborhood - on self-rated health in Brazil. The aim of the present study was to investigate the association between contextual aspects of neighborhoods on self-rated health among adults living in São Leopoldo, Rio Grande do Sul State, Brazil.

\section{Methods}

We carried out a population-based cross-sectional study of a representative sample of adults living in the urban area of the municipality of São Leopoldo, Southern Brazil. This municipality is located in the Rio dos Sinos Valley, within the metropolitan area of the state capital, Porto Alegre. The city's public service network includes one general hospital and 28 primary health care units. The city population in 2000 was 194,000 (IBGE.Cidades@.http://www.ibge.gov.br/ci dadesat/topwindow.htm?1, accessed on 17/Aug/ 2008).

Sample size was calculated based on data from a pilot study using the method for propor- tions with cluster randomization 29 , with selfrated health status as the outcome. Sample size was calculated to achieve $85 \%$ power $(1-\beta=0.85)$ to detect a difference of $7 \%$ in prevalence of poor self-rated health status between areas with high and low levels of social capital, with a confidence level of $95 \%$. This calculation was based on the following assumptions: prevalence of poor selfrated health of $13.3 \%$ (low social capital) and $4.9 \%$ (high social capital); intraclass correlation coefficient of 0.05 , and a total of 35 households per tract. The sample size for the number of households was increased by $20 \%$ to compensate for potential losses and for confounder control, and by a further $10 \%$ for the number of tracts for potential losses, yielding a total of 1,512 households in 40 census tracts.

Sampling began by the random selection of 40 of the city's 270 urban census tracts. Within each tract, we randomly selected one block, and all households were visited until the required number of 38 households was reached. If this number was still not reached after completion of the block, the interviewer would proceed to a second block, also selected randomly. Where blocks contained more than the required number of households, a corner was randomly selected and the corner household visited. Subsequent households to the left of an observer standing with his back turned to the initial household were then selected, i.e., the block was covered with the interviewer proceeding in an anti-clockwise direction. In case the household was absent, the interviewer returned to the household up to three more times.

Data were collected at two levels, individual and neighborhood (defined as a census tract) 30 . At the individual level, we collected information by means of structured interviews, using a standardized, pre-coded, and pre-tested questionnaire which included the outcome as well as items on demographic, socioeconomic, and behavioral variables. Questionnaires were administered at home to the person responsible for the household at the time of the interview. Persons under the age of 18 were excluded. The outcome variable - self-rated health status - was collected by the question "Generally speaking, would you say that your health is?", answer alternatives being categorized as "good (excellent/very good/ good) and poor (fair/poor). Demographic variables were: sex, age (10-year strata), observed skin color (white and nonwhite), and marital status (married/domestic partnership, single, and other). Individual socioeconomic variables included family income (in Brazilian Reais - R\$) and schooling (in years of study), later categorized as high (upper $25 \%$ of scores), middle (intermediate 
$50 \%$ ), and low (lower 25\%). Behavioral variables investigated were: fruit and vegetable intake (low intake: none; moderate intake: 1 or 2 fruits/day and 1-4 spoonfuls of vegetables/day; high intake: $\geq 3$ fruits/day and $\geq 5$ spoonfuls of vegetables/ day), smoking (nonsmoker, former smoker, and smoker), physical activity (sedentary: no physical activity; irregularly active: $<150 \mathrm{~min} /$ week; regularly active: $\geq 150<999 \mathrm{~min} /$ week; and very active: $\geq 1,000 \mathrm{~min} /$ week) 31 , and alcohol intake (none/ moderate intake: $<8 \mathrm{mg}$ + and $<15 \mathrm{mg}$; ; and yes/excessive intake: $\geq 8 \mathrm{mg} q$ and $\geq 15 \mathrm{mg}$ \) 32 . We also collected information on the number of medical appointments in the previous month (0, 1, and $\geq 2$ appointments), hospital admission in the past 12 months (yes/no), and presence of morbidities (0, 1-2, and $\geq 3$ morbidities).

Data for the neighborhood level were obtained from the 2000 census 30 , as well as by grouping data from the cross-sectional study by tract. Census tracts are the smallest unit of information available from the 2000 Brazilian census. São Leopoldo has 272 such tracts, with an average of 215 households and 704 inhabitants per tract. Sociodemographic variables available at this level are: number of inhabitants (or population living in the tract), nominal monthly income of heads of permanent private households, and total years of schooling of heads of permanent private households. The environmental context was evaluated based on the following variables: fraction of permanent private households with garbage disposal, bathroom or toilet, and connection to sewage network or pluvial sewage. Other contextual information was obtained based on the cross-sectional study, with answers aggregated at the neighborhood level; these included: percentage of the population of the tract that considered the area as polluted/very polluted, noisy/very noisy, and dirty/very dirty. These variables were categorized as: high (25\% highest scores among neighborhoods), middle (50\% intermediate scores), and low (25\% lowest scores). The same procedure was adopted for the variable participation in associations, obtained based on a question on regular participation (at least once a month) in associations in the past 3 years.

A pilot study with 100 subjects served as a basis for testing instrument quality and verifying the methods and logistics of the study. We also carried out quality control by telephone in a random sample of $10 \%$ of subjects participating in the study. For this purpose, we used an instrument similar to that used in the original study, but shorter, and which included only variables that were unlikely to change over a short period.

Data was entered twice using EpiInfo 6.0 software (Centers for Disease Control and Prevention,
Atlanta, USA), so as to allow for later comparison of databases and correction of entry mistakes. Data analysis was carried out using SPSS 13.0 (SPSS Inc., Chicago, USA) and MLwiN 2.10 software (Centre for Multilevel Modelling, Bristol, UK). Since the outcome was dichotomous, we carried out multi-level logistic regression with a $2^{\text {nd }}$ order predictive quasi-likelihood (PQL) approach, that provides more precise estimates for this type of data. Data analysis followed a hierarchical model, with a distal level - the focus of the present study - comprising sociodemographic and infrastructure characteristics of the neighborhood, and a second level composed of blocks of intermediate and proximal variables (Figure 1).

Neighborhood variables were selected for analysis as follows: the eight variables initially investigated were included in a model with backward exclusion of variables with significance greater than $5 \%$. This aimed to identify the most important neighborhood variables for the population studied, and avoid collinearity. In this process, only income and population remained associated with the outcome. The same procedure was adopted for selecting variables at the individual level, with sex, age, skin color, marital status, schooling, fruit and vegetable intake, number of medical appointments, and presence of morbidities remaining associated with the outcome. Multivariate analysis was carried out using four models. Initially, pre-selected neighborhood variables were adjusted for each other; we then included individual sociodemographic variables, and subsequently behavioral, service-related, and morbidity variables in the model; finally, a single neighborhood variable at a time was controlled for all individual variables. We adopted a $5 \%$ significance $(p<0.05)$ level for detecting associations between variables.

The research protocol was approved by the UNISINOS Research Ethics Committee (CEP 04/034). Subjects signed a form of free and informed consent, and total confidentiality of data was assured.

\section{Results}

Of the predicted total, we were able to complete 1,100 interviews in 38 census neighborhoods. Uninhabited or commercial buildings accounted for $8 \%$, refusals for $4 \%$, and absent heads of household at the time of the interview, for $2 \%$ of losses. A single subject did not provide information on self-rated health status; therefore, a total of 1,099 subjects were analyzed.

Approximately $72 \%$ of subjects were female, $84 \%$ had white skin color, and $56 \%$ were married 


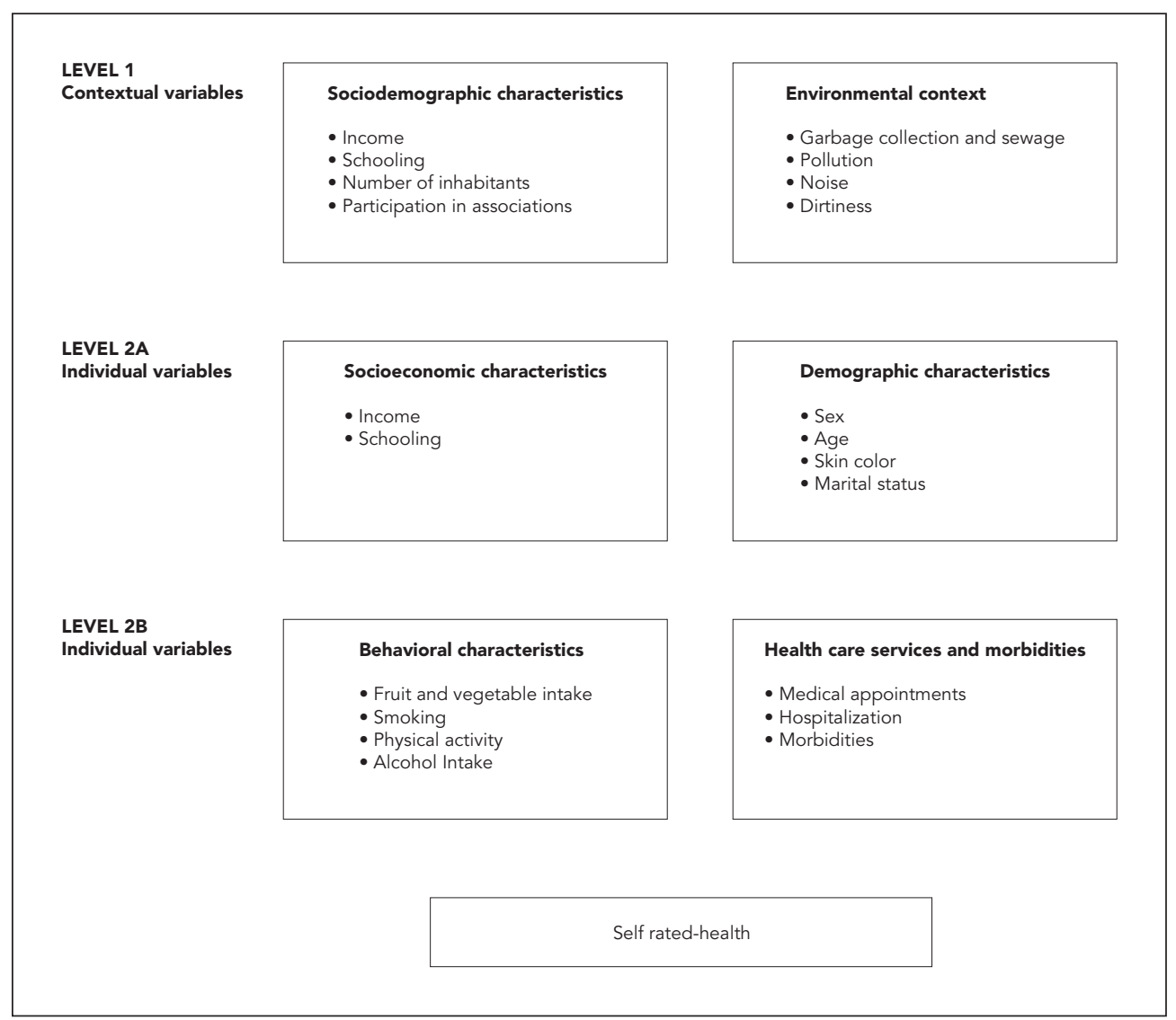

or living with a partner. Mean schooling was 8 years $(\mathrm{SD}=4)$ and mean family income was 7.5 times the minimum wage ( $\mathrm{SD}=7.4$ ). Prevalence of fair/poor self-rated health status was $32.7 \%$ (95\%CI: 30.0-35.5) (Table 1).

As to neighborhood characteristics, mean income and schooling of head of household was $\mathrm{R} \$ 955(\mathrm{SD}=586)$ and 8 years $(\mathrm{SD}=3)$, respectively. Mean neighborhood population was 746 inhabitants $(\mathrm{SD}=358)$. Mean percentage of households with regular garbage collection and sewage was $41 \%$. Mean percentage of subjects who considered their neighborhoods as polluted/very polluted, noisy/very noisy, and dirty/ very dirty was $27 \%(S D=27), 31 \%(S D=15)$, and $17 \%(\mathrm{SD}=13)$. Regular participation in associations was reported by approximately $37 \%$ (SD = 12) on average (Table 2).
More populous neighborhoods showed higher prevalence's of poor self-rated health, as did neighborhoods with lower mean income and schooling. For example, the odds of a subject showing poor self-rated health was five times higher among residents of low-income neighborhoods than among those of high-income neighborhoods $(\mathrm{OR}=5.05$; 95\%CI: 3.04-8.41). Likewise, the odds for poor self-rated health status was almost three times higher among residents of neighborhoods with larger populations than among those of low-population neighborhoods (OR = 2.64; 95\%CI: 1.65-4.22). Though not statistically significant, important effects (OR > 1.5) were detected for pollution and dirtiness in the area. Subjects living in more polluted or dirty neighborhoods also showed higher prevalence of the outcome (Table 2). 
Table 1

Distribution, prevalences and unadjusted odds ratio (OR) of fair/poor self-rated-health according to individual variables in Brazilian adults, 2007 ( $n=1.100$ ).

\begin{tabular}{|c|c|c|c|c|}
\hline Variables & $\mathrm{n}$ & $\%$ & $\begin{array}{c}\text { Prevalence of self } \\
\text { rated-health fair/poor } \\
{[\%(95 \% \mathrm{Cl})]}\end{array}$ & OR $(95 \% \mathrm{Cl})$ \\
\hline \multicolumn{5}{|l|}{ Sex } \\
\hline Male & 310 & 28.2 & $25.5(20.6-30.4)$ & 1.00 \\
\hline Female & 790 & 71.8 & $35.5(32.1-38.8)$ & $1.62(1.20-2.18)$ \\
\hline \multicolumn{5}{|l|}{ Age (years) } \\
\hline $18-29$ & 247 & 22.5 & $17.8(13.0-22.6)$ & 1.00 \\
\hline $30-39$ & 182 & 16.5 & $17.0(11.5-22.5)$ & $1.06(0.63-1.78)$ \\
\hline $40-49$ & 258 & 23.5 & $31.1(25.4-36.8)$ & $2.16(1.40-3.32)$ \\
\hline $50-59$ & 217 & 19.7 & $48.4(41.7-55.1)$ & $4.79(3.10-7.40)$ \\
\hline$\geq 60$ & 196 & 17.8 & $50.5(43.4-57.6)$ & $5.47(3.49-8.57)$ \\
\hline \multicolumn{5}{|l|}{ Skin color } \\
\hline White & 922 & 84.0 & $31.4(28.4-34.4)$ & 1.00 \\
\hline No white & 176 & 16.0 & $39.8(32.5-47.1)$ & $1.41(1.37-1.46)$ \\
\hline \multicolumn{5}{|l|}{ Marital status } \\
\hline Married/Domestic partnership & 615 & 55.9 & $31.3(27.6-35.0)$ & 1.00 \\
\hline Single & 267 & 24.3 & $24.7(19.5-30.0)$ & $0.72(0.51-1.00)$ \\
\hline Other & 218 & 19.8 & $46.3(40.0-53.0)$ & $1.94(1.41-2.68)$ \\
\hline \multicolumn{5}{|l|}{ Family income $(R \$$ *) } \\
\hline High $(\geq 3,185)$ & 268 & 25.1 & $17.2(12.7-21.8)$ & 1.00 \\
\hline Middle $(3,184-1,050)$ & 565 & 52.9 & $34.4(30.7-38.1)$ & $2.55(1.76-3.70)$ \\
\hline Low $(\leq 1,049)$ & 235 & 22.0 & $43.8(37.0-50.7)$ & $3.65(2.40-5.56)$ \\
\hline \multicolumn{5}{|l|}{ Schooling (years) } \\
\hline High $(\geq 12)$ & 166 & 18.0 & $8.4(4.1-12.7)$ & 1.00 \\
\hline Middle (5-11) & 552 & 59.9 & $35.2(31.3-39.2)$ & $4.50(2.50-8.11)$ \\
\hline $\operatorname{Low}(\leq 4)$ & 204 & 22.1 & $44.3(37.9-50.7)$ & $14.27(7.61-26.77)$ \\
\hline \multicolumn{5}{|l|}{ Fruit/Vegetable intake } \\
\hline High ( $\geq 3$ fruit/day; $\geq 5$ spoon vegetable/day) & 128 & 11.6 & $28.9(21.0-36.9)$ & 1.00 \\
\hline Middle (1-2 fruit/day; $1-4$ spoon vegetable/day) & 908 & 82.5 & $33.0(30.0-36.0)$ & $1.19(0.79-1.80)$ \\
\hline Low (no consumption) & 64 & 5.8 & $35.9(23.9-48.0)$ & $1.33(0.70-2.54)$ \\
\hline \multicolumn{5}{|l|}{ Smoking } \\
\hline Nonsmoker & 605 & 55.0 & $30.1(26.5-33.8)$ & 1.00 \\
\hline Former-smoker & 233 & 21.2 & $37.8(31.5-44.0)$ & $1.40(1.01-1.93)$ \\
\hline Smoker & 262 & 23.8 & $34.0(28.2-40.0)$ & $1.17(0.86-1.60)$ \\
\hline \multicolumn{5}{|l|}{ Physical activity (minutes/week) } \\
\hline High active $(\geq 1,000)$ & 128 & 11.7 & $25.8(18.1-33.5)$ & 1.00 \\
\hline Regular active $(\geq 150 \leq 999)$ & 441 & 40.2 & $29.5(25.2-33.8)$ & $1.23(0.78-1.95)$ \\
\hline Irregular active $(<150)$ & 244 & 22.3 & $35.2(29.2-41.3)$ & $1.60(0.98-2.60)$ \\
\hline Sedentary & 283 & 25.8 & $38.7(32.9-44.4)$ & $1.84(1.14-2.97)$ \\
\hline \multicolumn{5}{|l|}{ Alcohol intake } \\
\hline None/Moderate intake $(<8 \mathrm{mg}+$ and $<15 \mathrm{mg} \hat{\jmath} /$ day $)$ & 1,070 & 97.3 & $33.0(30.2-35.8)$ & 1.00 \\
\hline Yes/Excessive intake ( $\geq 8 \mathrm{mg}$ q and $\geq 15 \mathrm{mg} \delta /$ day) & 30 & 2.7 & $20.0(4.8-35.2)$ & $0.49(0.20-1.24)$ \\
\hline \multicolumn{5}{|l|}{ Medical appointments (last month) } \\
\hline 0 & 623 & 56.7 & $25.4(22.0-28.8)$ & 1.00 \\
\hline 1 & 231 & 21.0 & $32.9(26.8-39.0)$ & $1.44(1.03-2.02)$ \\
\hline$\geq 2$ & 244 & 22.2 & $51.2(44.9-57.5)$ & $3.19(2.33-4.38)$ \\
\hline \multicolumn{5}{|l|}{ Hospitalization (last 12 months) } \\
\hline No & 977 & 88.8 & $31.1(28.2-34.1)$ & 1.00 \\
\hline Yes & 123 & 11.2 & $44.7(35.8-53.6)$ & $1.75(1.19-2.57)$ \\
\hline \multicolumn{5}{|l|}{ Morbidities } \\
\hline 0 & 527 & 49.7 & $17.7(14.4-21.0)$ & 1.00 \\
\hline $1-2$ & 453 & 42.7 & $41.7(37.2-46.3)$ & $3.60(2.66-4.87)$ \\
\hline$\geq 3$ & 80 & 7.5 & $67.5(57.0-78.0)$ & $10.63(6.23-18.16)$ \\
\hline
\end{tabular}

Note: bold values are statistically significant $(p<0.05)$.

* US\$1 $=\mathrm{R} \$ 2$ (in 2006). 
Distribution, prevalences and unadjusted odds ratio (OR) of fair/poor self-rated-health according to neighborhood (census tract) variables in Brazilian adults, $2007(n=1,100)$.

\begin{tabular}{|c|c|c|c|c|}
\hline Variables & $\begin{array}{l}\text { Neighborhood } \\
{[\mathrm{n}(\%)]}\end{array}$ & $\begin{array}{l}\text { Individual } \\
\text { [n (\%)] }\end{array}$ & $\begin{array}{l}\text { Self rated-health } \\
\text { fair/poor } \\
{[\%(95 \% \mathrm{Cl})]}\end{array}$ & $\begin{array}{l}\text { Odds ratio } \\
(95 \% \mathrm{Cl})\end{array}$ \\
\hline \multicolumn{5}{|l|}{ Income $(R \$)$ * } \\
\hline High (P75\%: $\geq 1,362)$ & $9(23.7)$ & $185(16.8)$ & $16.2(10.9-21.6)$ & 1.00 \\
\hline Middle (<P75\% and > P25\%: 508.01-1,362.00) & $20(52.6)$ & $667(60.7)$ & $35.3(31.6-39.0)$ & $2.88(1.83-4.54)$ \\
\hline Low (P25\%: $\leq 508)$ & $9(23.7)$ & $248(22.5)$ & $37.9(31.8-44.0)$ & $5.05(3.04-8.41)$ \\
\hline \multicolumn{5}{|l|}{ Schooling (years) * } \\
\hline High (P75\%: $\geq 9.61)$ & $9(23.7)$ & $215(19.5)$ & $19.1(13.8-24.4)$ & 1.00 \\
\hline Middle (<P75\% and > P25\%: 5.61-9.6) & $20(52.6)$ & $593(54.0)$ & $35.0(31.1-38.8)$ & $2.33(1.52-3.55)$ \\
\hline Low (P25\%: $\leq 5.6)$ & $9(23.7)$ & $292(26.5)$ & $38.0(32.4-43.6)$ & $2.64(1.65-4.22)$ \\
\hline \multicolumn{5}{|l|}{ Population (inhabitants) * } \\
\hline Low (P25\%: $\leq 510)$ & $9(23.7)$ & $246(22.4)$ & $17.9(13.1-22.7)$ & 1.00 \\
\hline Middle (<P75\% and > P25\%: 511-908) & $20(52.6)$ & $548(49.8)$ & $37.5(33.4-41.5)$ & $2.77(1.89-4.06)$ \\
\hline High (P75\%: $\geq 909$ ) & $9(23.7)$ & $306(27.8)$ & $35.9(30.5-41.4)$ & $2.60(1.72-3.94)$ \\
\hline \multicolumn{5}{|l|}{ Garbage collection and sewage * } \\
\hline High (P75\%: $\geq 51.71)$ & $9(23.7)$ & $233(21.2)$ & $30.5(24.5-36.4)$ & 1.00 \\
\hline Middle (<P75\% and > P25\%: 4-51.7) & $21(55.3)$ & $611(55.5)$ & $31.8(28.1-35.5)$ & $1.19(0.77-1.84)$ \\
\hline Low (P25\%: $\leq 3.9)$ & $8(21.1)$ & $256(23.3)$ & $36.7(30.8-42.7)$ & $1.32(0.78-2.25)$ \\
\hline \multicolumn{5}{|l|}{ Participation in associations ** } \\
\hline High (P75\%: $\geq 46)$ & $10(26.3)$ & $286(26.0)$ & $32.9(27.4-38.3)$ & 1.00 \\
\hline Middle (< P75\% and > P25\%: 27.01-45.9) & $17(44.7)$ & $477(43.4)$ & $30.5(26.3-34.6)$ & $1.18(1.13-1.23)$ \\
\hline Low (P25\%: $\leq 27.0$ ) & $11(28.9)$ & $337(30.6)$ & $35.6(30.1-40.7)$ & $1.12(0.70-1.79)$ \\
\hline \multicolumn{5}{|l|}{ Pollution ** } \\
\hline Low (P25\%: $\leq 13.1)$ & $9(23.7)$ & $217(19.7)$ & $27.3(21.3-33.3)$ & 1.00 \\
\hline Middle (< P75\% and > P25\%: 13.2-32.1) & $20(52.6)$ & $664(60.4)$ & $33.6(30.0-37.2)$ & $1.42(0.89-2.25)$ \\
\hline High (P75\%: $\geq 32.12$ ) & $9(23.7)$ & 219 (19.9) & $35.2(28.8-41.5)$ & $1.56(0.89-2.72)$ \\
\hline \multicolumn{5}{|l|}{ Noise ** } \\
\hline Low (P25\%: $\leq 19.3$ ) & $9(23.7)$ & $214(19.5)$ & $28.5(22.4-34.6)$ & 1.00 \\
\hline Middle (< P75\% and > P25\%: 19.31-41.6) & $20(52.6)$ & $623(56.6)$ & $33.3(29.6-37.0)$ & $1.23(0.78-1.96)$ \\
\hline High (P75\%: $\geq 41.7$ ) & $9(23.7)$ & $263(23.9)$ & $34.6(28.8-40.4)$ & $1.36(0.79-2.31)$ \\
\hline \multicolumn{5}{|l|}{ Dirtiness ** } \\
\hline Low (P25\%: $\leq 8.7)$ & $9(23.7)$ & $254(23.1)$ & $27.7(22.1-33.2)$ & 1.00 \\
\hline Middle (< P75\% and > P25\%: 8.71-24.9) & $19(50.0)$ & $587(53.4)$ & $32.9(29.1-36.7)$ & $1.26(0.81-1.95)$ \\
\hline High (P75\%: $\geq 25$ ) & $10(26.3)$ & $259(23.5)$ & $37.1(31.2-43.0)$ & $1.57(0.95-2.59)$ \\
\hline
\end{tabular}

Note: bold values are statistically significant $(p<0.05)$.

* Source: Braziliam Institute of Geography and Statistics 30;

** Collected by the cross-sectional study and answers aggregated at the neighborhood level.

In multivariable analysis, neighborhood income and population were associated with the outcome when adjusted for each other (Table 3 , Model 1). When both were adjusted for socioeconomic, behavioral, service-related, and morbidity variables (Models 2 and 3), though an important effect remained, both variables lost statistical significance. However, statistical significance was maintained when the two variables in the neighborhood level were adjusted one at a time for all individual variables. The odds for poor selfrated health status was roughly two times higher among residents of neighborhoods with low in- come and large populations than among subjects from high-income/low-population neighborhoods (Table 3, Model 4a).

\section{Discussion}

The present study investigated the association between sociodemographic and environmental context and self-rated health status among adults. After adjustment for individual factors, subjects living in neighborhoods with low income and large populations showed higher prevalence of 
Table 3

Neighborhood effects in fair/poor self rated-health adjusted by individual variables in adults. São Leopoldo, Rio Grande do Sul State, Brazil, 2007 ( $\mathrm{n}=1,100$ )

\begin{tabular}{|c|c|c|c|c|}
\hline Variable & $\begin{array}{c}\text { Model } 1 \\
\text { OR }(95 \% \mathrm{Cl})\end{array}$ & $\begin{array}{c}\text { Model } 2 \\
\text { OR }(95 \% \mathrm{Cl})\end{array}$ & $\begin{array}{c}\text { Model } 3 \\
\text { OR }(95 \% \mathrm{Cl})\end{array}$ & $\begin{array}{c}\text { Model } 4 \\
\text { OR }(95 \% \mathrm{Cl})\end{array}$ \\
\hline \multicolumn{5}{|l|}{ Neighborhood income (R\$) } \\
\hline High (P75\%: $\geq 1,362.01)$ & 1.00 & 1.00 & 1.00 & 1.00 \\
\hline Middle (< P75\% and > P25\%: 508.01-1,362.00) & $1.78(1.03-3.07)$ & $1.55(0.81-2.98)$ & $1.10(0.53-2.30)$ & $1.78(1.01-3.17)$ * \\
\hline Low (P25\%: $\leq 508.00)$ & $1.82(0.99-3.35)$ & $1.39(0.65-2.96)$ & $1.34(0.57-3.12)$ & $2.29(1.16-4.50)$ * \\
\hline \multicolumn{5}{|l|}{ Neighborhood population (inhabitants) } \\
\hline Low (P25\%: $\leq 510)$ & 1.00 & 1.00 & 1.00 & 1.00 \\
\hline Middle (<P75\% and > P25\%: 511-908) & $1.96(1.21-3.18)$ & $1.70(0.96-3.02)$ & $1.88(0.97-3.64)$ & $2.11(1.27-3.50)$ * \\
\hline High (P75\%: $\geq 909$ ) & $1.80(1.08-3.01)$ & $1.54(0.84-2.85)$ & $1.89(0.92-3.85)$ & $2.04(1.15-3.61) *$ \\
\hline \multicolumn{5}{|l|}{ Sex } \\
\hline Male & - & 1.00 & 1.00 & 1.00 \\
\hline Female & - & $1.59(1.10-2.29)$ & $1.34(0.89-2.00)$ & $1.34(0.90-1.99) * \star$ \\
\hline \multicolumn{5}{|l|}{ Age (complete years) } \\
\hline $18-29$ & - & 1.00 & 1.00 & 1.00 \\
\hline $30-39$ & - & $0.81(0.46-1.44)$ & $0.78(0.42-1.46)$ & $1.28(0.68-2.40) * \star$ \\
\hline $40-49$ & - & $1.99(1.20-3.29)$ & $2.00(1.16-3.44)$ & $1.99(1.16-3.44) * *$ \\
\hline $50-59$ & - & $4.25(2.51-7.20)$ & $3.11(1.71-5.68)$ & $3.00(1.65-5.42) * *$ \\
\hline$\geq 60$ & - & $4.78(2.65-8.62)$ & $3.00(1.51-5.95)$ & $2.79(1.42-5.46) * \star$ \\
\hline \multicolumn{5}{|l|}{ Skin color } \\
\hline White & - & 1.00 & 1.00 & 1.00 \\
\hline No white & - & $1.49(0.99-2.23)$ & $1.26(0.81-1.95)$ & $1.38(0.89-2.13)$ ** \\
\hline \multicolumn{5}{|l|}{ Marital status } \\
\hline Married/Union & - & 1.00 & 1.00 & 1.00 \\
\hline Single & - & $1.41(0.93-2.13)$ & $1.87(1.19-2.94)$ & $1.90(1.21-2.99) * *$ \\
\hline Other & - & $1.27(0.84-1.93)$ & $1.27(0.80-2.01)$ & $1.29(0.82-2.04) * *$ \\
\hline \multicolumn{5}{|l|}{ Schooling (complete years) } \\
\hline High ( $\geq 12)$ & - & 1.00 & 1.00 & 1.00 \\
\hline Middle (5-11) & - & $3.37(1.82-6.24)$ & $3.93(1.99-7.76)$ & $4.71(2.42-9.15)$ ** \\
\hline $\operatorname{Low}(\leq 4)$ & - & $6.41(3.22-12.76)$ & $7.25(3.38-15.54)$ & $9.55(4.61-19.81)$ ** \\
\hline \multicolumn{5}{|l|}{ Fruit/Vegetable intake } \\
\hline High ( $\geq 3$ fruit/day; $\geq 5$ spoon vegetable/day) & - & - & 1.00 & 1.00 \\
\hline Middle (1-2 fruit/day; $1-4$ spoon vegetable/day) & - & - & $1.49(0.84-2.63)$ & $1.42(0.80-2.52)$ ** \\
\hline Low (no consumption) & - & - & $2.92(1.24-6.89)$ & $2.98(1.26-7.05) * \star$ \\
\hline \multicolumn{5}{|l|}{ Medical appointments (last month) } \\
\hline 0 & - & - & 1.00 & 1.00 \\
\hline 1 & - & - & $1.26(0.82-1.95)$ & $1.28(0.83-1.97)$ ** \\
\hline$\geq 2$ & - & - & $2.90(1.91-4.39)$ & $2.92(1.93-4.41)$ ** \\
\hline \multicolumn{5}{|l|}{ Morbidities (last 12 months) } \\
\hline 0 & - & - & 1.00 & 1.00 \\
\hline $1-2$ & - & - & $2.53(1.70-3.75)$ & $2.52(1.71-3.72)$ ** \\
\hline$\geq 3$ & - & - & $5.74(2.73-12.10)$ & $5.82(2.78-12.16)$ ** \\
\hline
\end{tabular}

Note: bold values are statistically significant $(p<0.05)$.

Model 1: neighborhood variables were adjusted for each other; Model 2: neighborhood variables were adjusted for each other and for individual sociodemographic variables; Model 3: neighborhood variables were adjusted for each other and for individual sociodemographic, behavioral, service-related, and morbidity variables; Model 4: * a single neighborhood variable at a time was adjusted for all individual variables; ${ }^{\star *}$ individual variables were adjusted for each other.

poor self-rated health status. It should be noted that the area variables were associated with each other. Neighborhoods with larger low-income populations also showed a greater proportion of low schooling, low levels of participation in as- sociations, and high levels of pollution and dirtiness. Likewise, more populous neighborhoods also showed lower schooling rates, less participation in associations and greater pollution and noise. 
Other Brazilian studies show strong associations between place of residence and individual health 11,25,26. A longitudinal study including 922 children under 3 years of age, living in 23 neighborhoods (census tracts) of Salvador, Northeastern Brazil, found daily incidence of diarrhea to be strongly associated with dirtiness and flooding in the neighborhood 21 . Such a result illustrates the association between physical conditions of the place of residence and individual health.

The effect of context-related variables on individual outcomes, having neighborhoods (census tracts) as the unit of analysis and self-rated health as the outcome, has previously been investigated only in studies conducted outside of Brazil 33,34,35,36,37,38,39,40. The results of the present study, confirm prior findings in the literature that characteristics of place of residence influence individual health perception. Places with lower mean income showed higher prevalences of poor self-rated health status. Such an association may be explained by the fact that poorer areas usually display characteristics that are unfavorable to good health. For example, an inadequate healthcare network, absence of sites for practicing physical activities, a poorly organized physical environment (accumulated garbage, depredation), faulty basic sanitation, transportation and education, and lower levels of social cohesion 33,34,38.

The results of this study demonstrate an important association between greater population and poor perceptions of health. The population size of the place of residence can influence individual perceptions of health status, since a large number of individuals living in the same neighborhood can lead to problems with organization and social participation, a disorderly environment, greater exposure to violence, and insufficient social cohesion ${ }^{34}$. Furthermore, the higher level of noise in places of high population density can affect health perception among residents, as can the higher level of environmental pollution $34,38,39$.

One of the major methodological limitations of studies that investigate context-related characteristics at the neighborhood level is defining what is meant by "neighborhood". Definitions based on people's perceptions may be pertinent in studies in which the context-related characteristics of interest include networks and social cohesion 41; administratively-defined neighborhoods may be important when the study hypothesis involves public policy; and geographicallydefined neighborhoods can be important when studying physical environment and structural characteristics. The present survey defined the neighborhood as a census tract, i.e., as a unit of analysis with a small number of inhabitants mean population being $746(\mathrm{SD}=358)$ persons $/$ tract. This, to a certain extent, validates the individual perception of these areas. A further limitation concerns study design. Studies with a crosssectional design are limited to identifying associations rather than causal relationships. Reverse causality may exist especially with individual level variables. For example, it can be argued that both subjects reported poorer health because they are sedentary or are sedentary because of limitations of their poor health. Therefore, longitudinal studies are essential to confirm the associations reported here. In addition, for logistical reasons, interviews were conducted during working hours. Because of this, more women took part in the survey. This is a common limitation of Brazilian household surveys. Although our sample did not have enough power to carry out stratified analyses, secondary analysis revealed that neighborhood effects were stronger for women compared to men. In this sense, one possible explanation would be that populous or poor neighborhoods could be worse for women because that is where they spend most of their time. Thus, they can benefit more from better health services or suffer more due to a lack of them in a wealthy or poor neighborhood. It is worthwhile mentioning that our findings agree with the literature in that women report worse self reported health and use health services more than do men. Therefore our results should be seen in the light of possible sex differences.

Positive aspects of the study should also be highlighted. We employ the design and analysis technique most adequate for reaching the proposed objective. Though originated in the fields of education, demographics, and sociology, multilevel analysis has recently begun to be used in collective health, in an attempt to determine the influence of social determinants on the health-disease process 1,42 . The rationale behind the use of this technique resides in the fact that the distribution of health and disease within a population cannot be explained based only on individual characteristics. Such analysis allows for the simultaneous evaluation of the effects of contextual and individual determinants, generating a clearer picture of the contribution of each of these levels to the outcome of interest 1. In addition, the neighborhood sample is representative of neighborhoods of São Leopoldo. Mean income, schooling, population and number of households of the studied census tracts were very close to those of all tracts in the municipality, suggesting that results obtained using our area variables can be extrapolated to the entire population of the municipality. On the other 
hand, it may not be appropriate to extrapolate data collected by means of a questionnaire and later grouped by census tract to the entire census tract of interest. Another aspect worth highlighting is the absence in Brazil of other studies using this type of analysis and self-perception of health as an outcome. Self-report is an important method for collecting health-related information among adults. It allows for the use of auxiliary personnel, which makes it ideal for use in collective interventions and a good indicator for planning and monitoring interventions. On the other hand, certain individuals may regard living with certain health conditions as normal, and thus report having good health even when clinically ill 43 .

Finally, our present findings are relevant as a source of information for future comparisons, and because they identify an association be tween context-related variables and self-rated health status. Further studies will be required to confirm the associations reported here, using different designs, outcomes, and exposures. We expect that this information will be useful as a tool for guiding health policies that include integral and multisector initiatives in accord with the needs of the population, and that are aimed at improving its quality of life.

\section{Resumo}

O objetivo foi investigar a associação entre o contexto sociodemográfico e ambiental e a autopercepção de saúde. Realizou-se um estudo transversal de base populacional com uma amostra aleatória de 38 vizinhanças (setor censitário) e 1.100 adultos de São Leopoldo, Rio Grande do Sul, Brasil. A análise dos dados utilizou regressão logística multinível. Dados do Instituto Brasileiro de Geografia e Estatística no ano 2000, as médias de renda e anos de estudo do chefe do domicílio, e o número de residentes por vizinhança eram $R \$ 955,00(D P=586), 8$ anos $(D P=3)$ e $746(D P=358)$, respectivamente. Após o controle por aspectos sociodemográficos, comportamentais e relacionados ao serviço no nível individual, as chances de relatar uma autopercepção de saúde como razoável ou ruim eram cerca de duas vezes maiores em vizinhanças mais populosas $(O R=2,04$; IC95\%: 1,15-3,61) e nas com baixa renda $(R P=2,29$; IC95\%: 1,16-4,50), quando comparadas às com baixo número de residentes e com alta renda. Resultados sugerem que a autopercepção de saúde depende das características do indivíduo e do contexto sociodemográfico em que ele vive.

Condições Sociais; Autoimagem; Adulto

\section{Contributors}

C. Cremonese conducted the study, collected contextual data, created the area-level database and wrote the manuscript. V. Backes helped in the data collection and creation of the database. M. T. A. Olinto helped in the manuscript discussion. J. S. Dias-da-Costa helped in the manuscript discussion. M. P. Pattussi supervised the study, data collection and data analysis. All authors reviewed the manuscript and interpreted results.

\section{Acknowledgments}

M. P. Pattussi was supported by National Research Council (CNPq; processes 478503/2004-0 and 481410/2009-0) and Rio Grande do Sul State Research Foundation (FAPERGS; process 0415621). 


\section{References}

1. Diez Roux AV. A glossary for multilevel analysis. Epidemiol Community Health 2002; 56:588-94.

2. Diez Roux AV. Bringing context back into epidemiology: variables and fallacies in multilevel analysis. Am J Public Health 1998; 88:216-22.

3. Kawachi I, Subramanian SV. Neighbourhood influences on health. J Epidemiol Community Health 2007; 61:3-4.

4. Santos SM, Chor D, Werneck GL, Coutinho ESF. Associação entre fatores contextuais e auto-avaliação de saúde: uma revisão sistemática de estudos multinível. Cad Saúde Pública 2007; 23:2533-54.

5. Diez Roux AV. Neighborhoods and health: where are we and were do we go from here? Rev Epidemiol Sante Publique 2007; 55:13-21.

6. Macintyre S, Ellaway A, Cummins S. Place effects on health: how can we conceptualize, operationalise and measure them? Soc Sci Med 2002; 55:125-39.

7. Idler EL, Angel RJ. Self-rated health and mortality in the NHANES-I epidemiologic follow-up study. Am J Public Health 1990; 80:446-52.

8. Heistaro S, Jousilahti P, Lahelma E, Vartiainen E, Puska P. Self rated health and mortality: a long term prospective study in eastern Finland. J Epidemiol Community Health 2001; 55:227-32.

9. Idler EL, Benyamini Y. Self-rated health and mortality: a review of twenty-seven community studies. J Health Soc Behav 1997; 38:21-37.

10. De Castro HA, Cunha MF, Mendonça GA, Junger WL, Cunha-Cruz J, de Leon AP. Effect of air pollution on lung function in schoolchildren in Rio de Janeiro, Brazil. Rev Saúde Pública 2009; 43:26-34.

11. De Alencar Ximenes RA, Martelli CM, MerchanHamann E, Montarroyos UR, Braga MC, De Lima ML, et al. Multilevel analysis of hepatitis A infection in children and adolescents: a household survey in the Northeast and Central-west regions of Brazil. Int J Epidemiol 2008; 37:852-61.

12. Hacker MA, Leite I, Friedman SR, Carrijo RG, Bastos FI. Poverty, bridging between injecting drug users and the general population, and "interiorization" may explain the spread of HIV in southern Brazil. Health Place 2009; 15:514-9.

13. Pattussi MP, Hardy R, Sheiham A. Neighborhood social capital and dental injuries in Brazilian adolescents. Am J Public Health 2006; 96:1462-8.

14. Pattussi MP, Hardy R, Sheiham A. The potential impact of neighborhood empowerment on dental caries among adolescents. Community Dent Oral Epidemiol 2006; 34:344-50.

15. Antunes JL, Peres MA, de Campos Mello TR, Waldman EA. Multilevel assessment of determinants of dental caries experience in Brazil. Community Dent Oral Epidemiol 2006; 34:146-52.

16. Antunes JL, Peres MA, Jahn GM, Levy BB. The use of dental care facilities and oral health: a multilevel approach of schoolchildren in the Brazilian context. Oral Health Prev Dent 2006; 4:287-94.

17. Antunes JL, Peres MA, Frias AC, Crosato EM, Biazevic MG. Gingival health of adolescents and the utilization of dental services, state of Sao Paulo, Brazil. Rev Saúde Pública 2008; 42:191-9.
18. Tassinari WS, de Leon AP, Werneck GL, Faerstein E, Lopes CS, Chor D, et al. Contexto sócio-econômico e percepção da saúde bucal em uma população de adultos no Rio de Janeiro, Brasil: uma análise multinível. Cad Saúde Pública 2007; 23:127-36.

19. Celeste RK, Nadanovsky P, De Leon AP. Association between preventive care provided in public dental services and caries prevalence. Rev Saúde Pública 2007; 41:830-8.

20. Frias AC, Antunes JL, Junqueira SR, Narvai PC. Individual and contextual determinants of the prevalence of untreated caries in Brazil. Rev Panam Salud Pública 2007; 22:279-85.

21. Rego RF, Barreto ML, Santos R, Oliveira NF, Oliveira S. Rubbish index and diarrhoea in Salvador, Brazil. Trans R Soc Trop Med Hyg 2007; 101:722-9.

22. Oliveira LP, Barreto ML, Assis AM, Braga-Junior AC, Nunes MF, Oliveira NF, et al. Determinants of linear growth retardation in Brazilian preschool children: a multilevel approach. Cad Saúde Pública 2007; 23:601-13.

23. Monteiro CA, Conde WL, Lu B, Popkin BM. Obesity and inequities in health in the developing world. Int J Obes Relat Metab Disord 2004; 28:1181-6.

24. Venancio SI, Monteiro CA. Individual and contextual determinants of exclusive breast-feeding in Sao Paulo, Brazil: a multilevel analysis. Public Health Nutr 2006; 9:40-6.

25. Werneck GL, Costa CH, Walker AM, David JR, Wand M, Maguire JH. Multilevel modelling of the incidence of visceral leishmaniasis in Teresina, Brazil. Epidemiol Infect 2007; 135:195-201.

26. Cavalini LT, de Leon AC. Morbidity and mortality in Brazilian municipalities: a multilevel study of the association between socioeconomic and healthcare indicators. Int J Epidemiol 2008; 37:775-83.

27. Zanini RR, de Moraes AB, Giugliani ER, Riboldi J. Infant mortality trends in the State of Rio Grande do Sul, Brazil, 1994-2004: a multilevel analysis of individual and community risk factors. Cad Saúde Pública 2009; 25:1035-45.

28. Lansky S, Subramanian SV, Franca E, Kawachi I. Higher perinatal mortality in National Public Health System hospitals in Belo Horizonte, Brazil, 1999: a compositional or contextual effect? BJOG 2007; 114:1240-5.

29. Hsieh FY. Sample size formulae for intervention studies with the cluster as unit of randomization. Stat Med 1988; 7:1195-201.

30. Instituto Brasileiro de Geografia e Estatística. Agregado dos setores censitários [CD-ROM]. Rio de Janeiro: Instituto Brasileiro de Geografia e Estatística; 2003.

31. Hallal PC, Victora CG. Reliability and validity of the International Physical Activity Questionnaire (IPAQ). Med Sci Sports Exerc 2004; 36:556.

32. World Health Organization. International guide for monitoring alcohol consumption and related harm. http://whqlibdoc.who.int/hq/2000/WHO_ MSD_MSB_00.4.pdf (accessed on 10/Sep/2008). 
33. Patel KV, Eschbach K, Rudkin LL, Peek MK, Markides KS. Neighborhood context and self-rated health in older Mexican-Americans. Ann Epidemiol 2003; 13:620-8.

34. Cummins S, Stafford M, Macintyre S, Marmot M, Ellaway A. Neighbourhood environment and its association with self rated health: evidence from Scotland and England. J Epidemiol Community Health 2005; 59:207-13.

35. Stafford M, Cummins S, Macintyre S, Ellaway A, Marmot M. Gender differences in the associations between health and neighbourhood environment. Soc Sci Med 2005; 60:1681-92.

36. Agyemang C, van Hooijdonk C, Wendel-Vos W, Lindeman E, Stronks K, Droomers M. The association of neighbourhood psychosocial stressors and self-rated health in Amsterdam, The Netherlands. J Epidemiol Community Health 2007; 61:1042-9.

37. Pampalon R, Hamel D, De Koninck M, Disant MJ. Perception of place and health: differences between neighbourhoods in the Quebec City region. Soc Sci Med 2007; 65:95-111.
38. Poortinga W, Dunstan FD, Fone DL. Perceptions of the neighbourhood environment and self rated health: a multilevel analysis of the Caerphilly Health and Social Needs Study. BMC Public Health 2007; 7:285.

39. Franzini L. Self-rated health and trust in low-income Mexican-origin individuals in Texas. Soc Sci Med 2008; 67:1959-69.

40. Wong IO, Cowling BJ, Lo SV, Leung GM. A multilevel analysis of the effects of neighbourhood income inequality on individual self-rated health in Hong Kong. Soc Sci Med 2009; 68:124-32.

41. Diez Roux AV. Investigating neighbourdhood and area effects on health. Am J Public Health 2001; (91):1783-9.

42. Diez Roux AV. Multilevel analysis in public health research. Annu Rev Public Health 2000; 21:171-92.

43. Bailis DS, Segall A, Chipperfield JG. Two views of self-rated general health status. Soc Sci Med 2003; 56:203-17.

Submitted on 17/Nov/2009

Final version resubmitted on $24 / \mathrm{Jun} / 2010$

Approved on 02/Aug/2010 